Vol. 11 (2002): 163-173.

\title{
Economic importance of parcel structure on Finnish farms
}

\author{
Sami Myyrä and Kyösti Pietola \\ MTT Agrifood Research Finland, Economic Research, Luutnantintie 13, FIN-00410 Helsinki, Finland, \\ e-mail: sami.myyra@mtt.fi
}

\begin{abstract}
This study estimates shadow prices for land parcel characteristics in Finland, such as size and distance from the compound, by adding these characteristics to the conditional profit maximisation model. The profit functions are production line-specific, and the endogenous choice of production line is controlled for by a switching-type Probit-model.

The results suggest that the small parcel size and their long distances from the compound significantly affect the farmer choice of allocating most land either to grass or to grain. The endogenous choice of line of production also has significant statistical implications in relation to profits, output supplies and input demand. Small parcel size was found to increase costs significantly by hindering farmers from adopting the most efficient production technologies and practices.

The ongoing rapid structural development in Finnish agriculture implies that the constraints imposed by small parcels of land are becoming more and more costly. Grassland farming is predicted to loose its comparative advantage in the most fragmented agricultural areas, as farm sizes increase further. Operations to re-structure parcels of land amongst a group of neighbouring farms, although often costly and time consuming, will generate high returns.
\end{abstract}

Key words: parcel size, parcel shape, parcel distance, self-selection, shadow prices

\section{Introduction}

The share of arable land from the total land area (including forests) in Finland is only eight percent. Arable land is distributed in small, usually unevenly shaped parcels that are scattered between forests, bed rock outcrops, wetlands, and/ or lakes. Therefore, a single farm of a moderate size will often be composed of a large number of small parcels of land located some distance away from the compound. The average parcel size is only 2.65 hectares and their area-weighted average distance from the farm compound is approximately 2000 metres.

Since the average farm has only 27.97 hectares of arable land, increasing of the farm size is one of the most important means in cutting down production costs and making Finnish agriculture more competitive on the European market. Small and remote parcels of land are likely to retard the efficient adoption of modern ma- 


\section{Myyrä, S. \& Pietola, K. Economic importance of parcel structure}

chinery and low-cost technologies, particularly on expanding farms. On the other hand, the local land markets are failing to reduce the problems caused by the disadvantageous parcel structure, as there is evidence that, for two reasons, trading in agricultural land tends to worsen the average parcel structure on farms that are expanding and intending to continue operation (Myyrä 2000). First, the traded parcels are smaller than average, suggesting that the local land market is affected by the adverse selection problem of Akerlof (1970). Land with lower than average parcel size and productivity comes onto the market. Second, available land is not usually located in the immediate neighbourhood, so that a farmer cannot merge purchased parcels with those that he already owns.

Although the disadvantageous parcel structure is expected to have important economic implications, not only increasing the current costs of farming but also hindering the expanding farms from taking full advantage of new technologies and economies of size, few estimates of these implications exist. These are largely restricted to the work of Singh and Ahn (1995) on the relationship between farm land structure and machinery efficiency, and of Sairanen (1998) and Aaltonen et al. (1999), who adopted normative approaches, such as enterprise budgets and the examination of representative farms, to estimate the additional costs driven up by a disadvantageous parcel structure.

This study takes a positive econometric approach to estimating and testing the shadow prices for certain parcel characteristics. One important advantage of our approach is that these shadow prices take into account the adjustments that farmers make to their operations, e.g. through input use and the crop mix, to allow for the distribution of their land parcels. Parcels that are far away from the compound may be cultivated more extensively than those that are close to the compound, for instance (Suomela 1950). The results can thus be expected to make an important contribution to the literature, and to have significant policy implications, in that they contain new information on the potential of Finnish agriculture to adjust to the European market by expanding farm size.

The next section of this article will sketch out the economic model and the technique for estimating its unknown parameters. The data are described in section 3, and the parameters and elasticity estimates are presented in section 4 . The last section contains concluding remarks and discusses the policy implications.

\section{The model}

\section{The profit maximization problem}

The economic model is based on the standard conditional profit maximization problem. In its general form, it assumes that a farmer will maximize short-term profits $(\pi)$ conditional a exogenously given set of current output prices $\left(p_{i}\right)$, input prices $\left(w_{j}\right)$, fixed factors $\left(k_{s}\right)$, and the technology constraint $T($.$) :$

\section{(1)}

$$
\begin{aligned}
& \pi\left(p_{1}, \ldots, p_{N}, w_{1}, \cdots, w_{M}, k_{1}, \cdots, k_{s}\right) \\
& =\max _{x, y}\left\{\sum_{i=1}^{t} p_{i} y_{i}-\sum_{j=1}^{J} w_{j} x_{j}: T(x, y, k), p>0, w>0\right\}
\end{aligned}
$$

where $y_{i}$ is the output $i$ and $x_{j}$ is the input $j$ for $i$ $=1,2, \ldots I$, and $j=1,2, \ldots J$. The technology constraint $T($.) gives mappings between outputs $y$ and inputs $x$ that are conditional on the amount of fixed inputs $k_{s}$, for $\mathrm{s}=1,2, \ldots S$. The set of fixed inputs is augmented by the parcel characteristics. The technology and the profit meet the standard regularity conditions (e.g. Chambers 1988).

The optimal decision rules, i.e. the output supplies and input demands, are then derived using the envelope theorem in the profit maximization problem (1), which gives

(2a) $\partial \pi(.) / \partial p_{i}=y_{i}($.$) for all i=1, \ldots, I$ and

(2b) $\partial \pi(.) / \partial w_{j}=-x_{j}($.$) for all j=1, \ldots, J$. 
Vol. 11 (2002): 163-173.

\section{The self-selection problem: endogenous choice of production line}

It is likely that the parameters of the profit and demand-supply system (1-2) will depend on the farms' production lines. More particularly, the effects of parcel characteristics are expected to be different on cattle farms, which allocate a significant proportion of their land to grass, from those farms that allocate most of their land to grain. We therefore stratify the model into two regimes and define production-line specific profits such that:

$$
\begin{aligned}
\pi^{l}= & \text { profit of farms allocating most land to } \\
& \text { grasses (have cattle) } \\
\pi^{2}= & \text { profit of farms allocating most land to } \\
& \text { grains (do not have cattle) }
\end{aligned}
$$

The corresponding demand-supply systems are then given by

(3a) $\partial \pi^{q}(.) / \partial p_{i}=y_{i}^{q}($.$) for all i=1, \ldots, I$ and (3b) $\partial \pi^{q}(.) / \partial w_{j}=-x_{j}^{q}($.$) for all j=1, \ldots, J$

where $q=1,2$ such that $q=1$ refers to the grass farms and $q=2$ refers to the grain farms.

We also expect parcel structure to have played a significant role in farmers' decisions to switch from cattle rearing to other lines of production and to reallocate land from grass to grain. Thus, even if we estimate the profit and demandsupply system separately for grassland farms and grain farms, it is likely that the self-selection problem, driven by the endogenous choice of production line, will cause a bias in the parameter estimates (Heckman 1979). To highlight the solution to this self-selection problem, we denote the profit of farms of type $q$ by

$$
\pi^{q}=Z \beta^{q}+u^{q}
$$

where $Z=(p, w, k)$ is a set of exogenous instruments, $\beta^{q}$ is a vector of parameters, and $u^{q}$ is an error. Zero restrictions on $\beta^{q}$ are used to specify the production-specific sets of instruments, which are subsets of $Z$.

A farmer allocates most of his land to grass $(q=1)$ if

$$
\pi^{1}-\pi^{2}>0 \Rightarrow u^{2}-u^{1}<Z \beta^{1}-Z \beta^{2} .
$$

Defining $v=u^{2}-u^{1}$ and $Z \beta=Z \beta^{1}-Z \beta^{2}$, this inequality can be simplified to $v<Z \beta$, which implies that, for normally distributed errors, $E[v \mid v<Z \beta] \neq 0$. The self-selection problem is significant if the covariance $\left(\sigma^{q}\right)$ between the errors in the choice equation $(v)$ and the profit equation $\left(u^{q}\right)$ differs from zero.

To obtain unbiased estimates for the parcel characteristics, the self-selection problem is controlled for by estimating

(6a) $\pi^{l}=Z \beta^{l}+\sigma^{l} E[v \mid v<Z \beta]+\varepsilon^{l}$, for grass farms, and

(6b) $\pi^{2}=Z \beta^{2}+\sigma^{2} E[v \mid v>Z \beta]+\varepsilon^{2}$, for grain farms,

where $\sigma^{q}=\operatorname{cov}\left(v, u^{q}\right)$ and $\varepsilon^{q}$ is an i.i.d. error with zero mean (Maddala 1993, p. 223-225). Given normally distributed errors

(7a) $E[v \mid v<Z \beta]=\frac{\phi(Z \beta)}{\Phi(Z \beta)}$ and

(7b) $E[v \mid v>Z \beta]=\frac{\phi(Z \beta)}{1-\Phi(Z \beta)}$,

where $\phi$ refers to the standard normal distribution function and $\Phi$ is the standard normal cumulative distribution function. These expressions are known as Inverses of Mill's Ratios (IMR) and are computed for each farm conditional on the estimated parameter vector $\beta$ and the farm-specific entries in $Z$. These IMRs measure the probability of a farm belonging to regime $q$, i.e. the probability that the farmer has chosen production line $q$. The notation is simplified here by considering only the profit function. The input demands and output supplies are corrected accordingly. 


\section{Myyrä, S. \& Pietola, K. Economic importance of parcel structure}

\section{Estimation method}

The self-selection problem, as described above, suggests a two-stage estimation approach, known as Heckman's (1979) two-stage method. The approach is to first estimate the choice of the line of production line using the Probit model and then calculate estimates for the IMRs for each farm. In the second stage, the profit and demand-supply system are estimated conditional on the model instruments and the estimated IMRs.

An alternative approach could be to estimate the choice probabilities, profits and demand-supply system jointly by the Full-Information Maximum-Likelihood method (FIML). We nevertheless estimate the model by Heckman's two-stage method because it is empirically attractive and is known to generate consistent parameter estimates.

The choice equation is estimated using a static binary choice model, since modelling the dynamics involved in a sequence of choices would have required a sampling period of more than two years and would also have resulted in identification problems in terms of extremely low annual response probabilities. The dynamics in a binary choice problem could be modeled and simulated as a sequence of interrelated choices (e.g. Keane 1993). This approach is not feasible with our data, however, since most switches occurred before the sampling period.

\section{Elasticity and shadow price estimates}

The elasticity of the response probabilities with respect to changes in the model variables is estimated by:

(8a) $\varepsilon_{i}=\frac{\partial \Phi\left(Z \beta^{1}\right) / \Phi\left(Z \beta^{1}\right)}{\partial z_{i} / z_{i}}=\frac{z_{i}}{\Phi\left(Z \beta^{1}\right)} \phi\left(Z \beta^{1}\right) \beta_{i}^{1}$

(grassland farms)

(8b) $\begin{aligned} \varepsilon_{i} & =\frac{\partial\left[1-\Phi\left(Z \beta^{2}\right)\right]\left[1-\Phi\left(Z \beta^{2}\right)\right]}{\partial z_{i} / z_{i}} \\ = & \frac{-z_{i}}{1-\Phi\left(Z \beta^{2}\right)} \phi\left(Z \beta^{2}\right) \beta_{i}^{2} \text { (grain farms) }\end{aligned}$ and the shadow price estimate for a fixed input $k_{s}$ in the line of production $q$ is given by

(9) $\partial \pi^{q}(.) / \partial k_{s}$.

\section{Empirical specification}

The profit function is defined as a quadratic, second order approximation having the following logarithmic form (dropping the superscripts indicating the line of production in connection with profit and the parameters):

$$
\begin{aligned}
\pi & =\beta_{0}+\sum_{q=1}^{2} \beta_{q} \ln \left(p_{q}\right)+\beta_{3} \ln (w)+\sum_{s=4}^{8} \beta_{s} \ln \left(k_{s}\right) \\
(10)+ & \sum_{q=1}^{2} \sum_{s=1}^{5} \beta_{q s} \ln \left(p_{q}\right) \ln \left(k_{s}\right)+\sum_{s=1}^{5} \beta_{3 s} \ln (w) \ln \left(k_{s}\right) \\
& +\frac{1}{2} \sum_{j=4}^{8} \sum_{s=4}^{8} \beta_{j s} \ln \left(k_{j}\right) \ln \left(k_{s}\right)
\end{aligned}
$$

where $p_{q}$ is the price index for the output $q$ and $w$ is the price index for the inputs. The vector for fixed inputs $K=\left(k_{1}, \ldots k_{5}\right)$ includes the area of arable land, farm capital, labour, the average distance of the parcels of land from the compound, and the average parcel size. Since we have only two years of data, the quadratic price effects could not be identified and had to be dropped (they are included in the reduced form intercept $\beta_{0}$ ). The first order price effects and the cross effects between the own price and fixed inputs are identified through the demand and supply equations. The supply equations take the form (again dropping the subscripts indicating the line of production chosen by the farm):

$$
y_{i}=\left[\beta_{i}+\sum_{s=1}^{5} \beta_{i s} \ln \left(k_{s}\right)\right] / p_{i}
$$

for $i=1$ : supply of livestock products and $i=2$ : supply of crop products

and the input demand is

(12) $x=-\left[\beta_{3}+\sum_{s=1}^{5} \beta_{3 s} \ln \left(k_{s}\right)\right] / w$ 
Vol. 11 (2002): 163-173.

To obtain a zero mean error in the profit, demand and supply equations (10-12), these were each augmented by the corresponding IMRs as given in (7).

Given these specifications, the shadow prices for the fixed factors take the form

$$
\begin{aligned}
& \text { (13) } \partial \pi / \partial k_{s}=\left[\beta_{s}+\beta_{1 s} \ln \left(p_{1}\right)+\beta_{2 s} \ln \left(p_{2}\right)\right. \\
& \left.+\beta_{3 s} \ln (w)+\sum_{j=4}^{8} \beta_{j s} \ln \left(k_{j}\right)\right] / k_{s}
\end{aligned}
$$

\section{Data}

The data are from two main sources. The economic farm accounts are from the FADN farm accountancy network (MTT) and comprise data on 962 farms in 1997 and 1998 (Table 1). Farms having more than one compound were dropped from the data. Farm profit is the net return on farm assets and the farmers' own family labour. Labour is measured in hours worked and land area in hectares. Capital includes machinery, buildings and livestock and is measured in units of FIM 1,000. Input is measured by a single quantity index. The most important composites in the index are fertiliser, feed concentrates, and energy.

The parcel size and distance data are from the parcel register maintained at the Ministry of Agriculture. The parcel size is the average size of all parcels on the farm, and is measured in hectares, while the distance is the area-weighted average direct distance, measured in kilometres, from the compound to a point in the middle of the parcel. The distance measured by road was unobserved in the data.

An average sample farm allocating most land to grass had 14.6 parcels of 2.26 hectares each at an average distance of 1.15 kilometres from the compound. Grain farms had an average of 12.6 parcels of 3.13 hectares each at a distance of 1.12 kilometres from the compound.

\section{Results}

\section{Choice of line of production}

Six out of the ten parameter estimates in the Probit model differ significantly from zero (Table 2). The land area of the farm, distance of the parcels from the compound and parcel size all have statistically significant effects on the choice of line of production.

Within the sample, the model predicts the choice of line of production correctly in 67 percent of cases (989 out of 1475 observations), but is inclined to over-predict the allocation of land to grass (Table 3). The number of observations on grass land farms is predicted at 940 whereas the observed number of these cases in the sam-

Table 1. Sample statistics.

\begin{tabular}{lcccc}
\hline & Grain farms & Range & Grass farms & Range \\
\hline Number of observations & 685 & & 790 & \\
Profit, FIM $*$ & 27,100 & & 48,660 & \\
Farm size, ha & 39.4 & $2.2-163.0$ & 33.0 & $8.5-266.6$ \\
Capital, FIM $* *$ & 520,000 & & 600,000 & \\
Work, h & 2,100 & $80.0-12,990$ & 4,620 & $730-11,700$ \\
Average distance of parcels, km & 1.12 & $0.08-63.0$ & 1.15 & $0.1-25.27$ \\
Average size of parcels, ha & 3.13 & $0.43-13.57$ & 2.26 & $0.75-27.83$ \\
\hline
\end{tabular}

$*$ profit $=$ the net return on farm assets and the farms' own family labour

** machinery, buildings and livestock 


\section{Myyrä, S. \& Pietola, K. Economic importance of parcel structure}

Table 2. Parameter estimates and their t-values in the Probit model.

\begin{tabular}{lcc}
\hline Variable & Estimate & t-value \\
\hline Intercept & 1.25 & 10.0 \\
Land area & 0.0191 & 0.376 \\
Parcel distance & -0.0255 & -0.725 \\
Parcel size & -0.464 & -6.49 \\
Land area squared $\cdot 0.5$ & -0.0151 & -2.85 \\
Parcel distance squared $\cdot 0.5$ & -0.00486 & -2.59 \\
Parcel size squared $\cdot 0.5$ & 0.0203 & 2.51 \\
Land area $\cdot$ parcel distance & 0.0239 & 2.34 \\
Land area $\cdot$ parcel size & 0.106 & 1.27 \\
Parcel distance $\cdot$ parcel size & -0.00198 & -0.124 \\
\hline
\end{tabular}

Note that regularity conditions in the production technologies do not impose restrictions on the choice equation, which is determined as the difference between two profit functions, and hence between two technologies.

ple is 790. The number of observations representing grain farms is under-predicted at 535 but the observed number of cases is 685 . The Probit model nevertheless gives a reasonable fit in view of the short time span covered by the data in relation to the characteristics of the choice problem being modelled.

The elasticity estimates suggest that the choice of line of production responds in-elastically to farm size and parcel distance, whereas likelihood of specialisation in grain cultivation increases elastically with parcel size (Table 4).

\section{The profit-supply-demand system}

The joint effects of the variables measuring parcel structure are significant at the one per cent
Table 3. Predicted and observed choices within the sample.

\begin{tabular}{lccr}
\hline Observed & \multicolumn{3}{c}{ Predicted } \\
\cline { 2 - 4 } & grain & grass & total \\
\hline Grain & 367 & 318 & 685 \\
Grass & 168 & 622 & 790 \\
Total & 535 & 940 & 1475 \\
\hline
\end{tabular}

level, their F-test statistics being 12.66 for grass farms and 15.96 for grain farms. Parcel size in particular got statistically significant parameter estimates in both lines of production. On the other hand, none of the terms that included parcel distance was significant alone, nor did the terms achieve joint significance in the standard F-test. Therefore, all the terms that included parcel distance were dropped from the model, and only the restricted version of the model is reported below. The parameter estimates and their t-values are given in Appendix 1.

The model gives a reasonable fit for a pooled two year data panel (Table 5). The only exception is the supply of crop products on farms allocating most of their land to grass (Table 5), a supply that is marginal and unpredictable, because most of the output consists of livestock and dairy products.

\section{Shadow prices for fixed factors}

At the mean values for the sample, the shadow prices for parcel size (equation 9) were estimated at FIM 8,400 per hectare for grass farms and at FIM 3,200 per hectare for grain farms (Ta-

Table 4. Elasticity of the response probabilities with respect to the variables in the model.a)

\begin{tabular}{lccrrrr}
\hline & \multicolumn{2}{c}{ Grass farms } & & \multicolumn{2}{c}{ Grain farms } \\
\cline { 2 - 3 } \cline { 5 - 6 } & Choose grass & Choose grains & & Choose grass & Choose grains \\
\hline Farm size & 0.06 & -0.10 & & 0.12 & -0.12 \\
Parcel distance & 0.05 & -0.08 & & 0.11 & -0.11 \\
Parcel size & -0.59 & 0.96 & & -0.99 & 0.95 \\
\hline
\end{tabular}

a) Elasticity estimates are evaluated at the sample means for grass and grain farms. 
Vol. 11 (2002): 163-173.

Table 5. Coefficient of determination $\left(\mathrm{R}^{2}\right)$ of the estimated profit supply and demand functions.

\begin{tabular}{lcccc}
\hline & Profit & $\begin{array}{c}\text { Supply of crop } \\
\text { products }\end{array}$ & $\begin{array}{c}\text { Supply of livestock } \\
\text { products }\end{array}$ & $\begin{array}{c}\text { Demand } \\
\text { for inputs }\end{array}$ \\
\hline Grass farms & 0.33 & 0.08 & 0.58 & 0.61 \\
Grain farms & 0.39 & 0.27 & 0.34 & 0.44 \\
\hline
\end{tabular}

Table 6. Shadow price estimates for fixed factors (equation 13). ${ }^{\text {a) }}$

\begin{tabular}{lcccc}
\hline & $\begin{array}{c}\text { Parcel size } \\
\text { FIM per hectare }\end{array}$ & $\begin{array}{c}\text { Labour } \\
\text { FIM per hour }\end{array}$ & $\begin{array}{c}\text { Land } \\
\text { FIM per hectare }\end{array}$ & $\begin{array}{c}\text { Capital } \\
\text { per cent }\end{array}$ \\
\hline Grass farms & 8,400 & 30 & 6,300 & 9.6 \\
Grain farms & 3,200 & 90 & 6,900 & 81 \\
\hline
\end{tabular}

a) The estimates are evaluated at the sample means for grass and grain farms.

ble 6). Thus, if the average parcel size were increased by one hectare, the annual profit of a grass farm could be predicted to increase by FIM 8,400 and the annual profit of a grain farm by FIM 3,200. The shadow price for labour was estimated within a plausible range of FIM 3090 per hour. The shadow price estimates for the land area of farms are plausible, even though they do suggest capitalised values for land that are above the observed market values (e.g. FIM $6,900 / 9 \%=$ FIM 77,000). Nevertheless, the high shadow price estimates for land support the view that farming has the potential for economically significant economies of size.

The shadow prices for parcel size increase elastically in both lines of production with the land area of the farm (Table 7). Therefore, the current trend for farm sizes to increase while parcel size remains constant, is predicted to increase welfare losses (e.g. costs) caused by the fragmented parcel structure.

Farm capital, such as machinery, has a negative effect on the shadow price of parcel size on grass farms but a positive effect on grain farms. These opposite signs are plausible, since the new roll-baling technology, adopted by many Finnish cattle farms in the 1990s is flexible. It allows for more efficient harvesting under fragmented parcel structure than the traditional technologies. In the grain sector, on the other hand,
Table 7. Elasticity estimates for the shadow prices of parcel size. ${ }^{\text {a) }}$

\begin{tabular}{lcc}
\hline Variable $\left(k_{s}\right)$ & Grass farms & Grain farms \\
\hline Land & 6.42 & 5.17 \\
Capital & -2.15 & 5.95 \\
Labour & 1.04 & 7.41 \\
Parcel size & -6.16 & -25.0 \\
\hline
\end{tabular}

a) estimated as $\left(\partial^{2} \pi / \pi\right) /\left(\partial k_{s} \partial k_{4} / \bar{k}_{4}\right)$, where $k_{4}=$ parcel size and the bar refers to the sample average.

the new low-cost technologies designed for large areas are inflexible and cannot be adapted to small parcels of land.

Parcel size has an elastic negative effect on the shadow price, i.e. if a farm's parcels of land become larger, the shadow price attributable to parcel size will decrease elastically.

\section{The present value of re-structuring parcels}

Since the parcels of land on most farms are fragmented, there is a potential for reducing the number and increasing their size by re-structuring among a group of farms. Each farm participating in the operation would benefit in terms of increased future profits (ceteris paribus) if the parcel size were increased, even though the to- 
Myyrä, S. \& Pietola, K. Economic importance of parcel structure

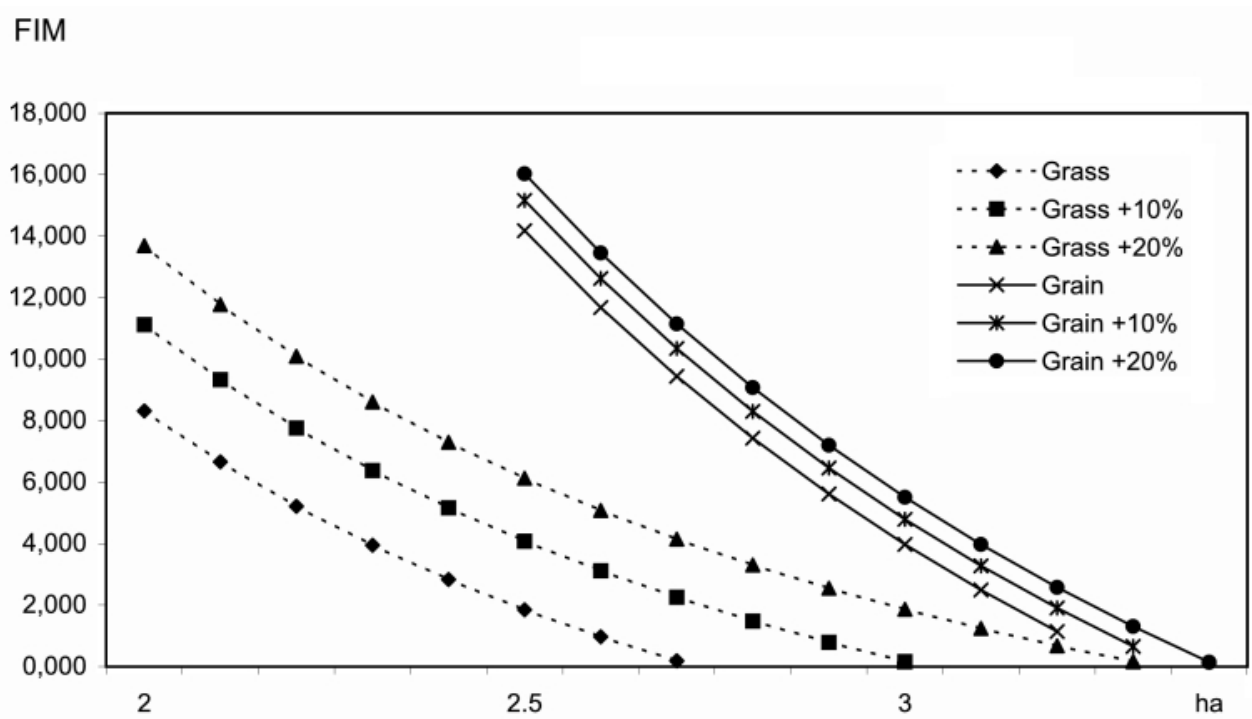

Fig. 1. Present values (Maximum bid prices) of increasing parcel size by 0.1 hectares at various parcel sizes (x-axis) on grass farms (33 ha, $33 \mathrm{ha}+10 \%$ and $33 \mathrm{ha}+20 \%)$ and grain farms (39.4 ha, $39.4 \mathrm{ha}+$ $10 \%$ and 39.4 ha $+20 \%$ ). Increase in farm size describes the ongoing rapid structural development in Finnish agriculture.

tal land area of each farm were to remain constant. The estimated present value per farm at the margin that could be gained through an operation that increased parcel size by 0.1 hectares is shown in Figure 1, where the future benefits are discounted at a rate of 5 per cent over a period of 20 years. The threshold curves in the Figure can also be interpreted as maximum bid prices for such re-structuring operations.

A re-structuring operation is in practice costly because any alteration in land ownership entails high transactions costs. Around the means for the two lines of production, a 0.1 hectare increase in parcel size would yield a present value of FIM 3,800 on grass farms and FIM 1,400 on grain farms. There is a potential for doubling the average parcel size in the most fragmented agricultural areas of western Finland, however, where the proportion of the total land area in arable use is high, and these improvements would generate returns that are well above the costs of the operation.

The maximum bid prices decrease quickly as the initial parcel size increases (ceteris paribus).
The benefits become negligible for an average parcel size that exceeds 3.3 hectares. Note, however, that 75 per-cent of the Finnish land parcels are smaller than 3.3 hectares, although these account for only about one third of the aggregate land area.

The shadow price for parcel size increases faster on grass farms than on grain farms as the farm size increases. Therefore, the ongoing fast structural development is expected increase the shadow price for parcel size more on grass land farms than grain farms.

\section{Self-selection}

The endogenous choice of line of production correlates significantly with production line specific profits, supplies and demand, when the correlation is measured in terms of the parameters attached to the IMRs (Appendix 1). Thus, the self selection problem is statistically significant so that stratifying the sample exogenously into lines of production and, then, estimating the prof- 
Vol. 11 (2002): 163-173.

its, supplies, and demands for the two lines separately would have generated biased estimates.

\section{Concluding remarks}

This study has estimated shadow prices for certain parcel characteristics on Finnish farms. Farm profit, output supplies and input demand were estimated jointly such that the endogenous choice of the production line was controlled for by Heckman's two-stage approach. The model was then simulated to obtain maximum bid prices for the re-structuring of parcels.

The results suggest that the small parcel size and their long distances from the compound have significant effects on farming in Finland. Both of these characteristics affect the farmer choice of line of production, i.e., the decision to allocate most land either to grass or to grain. In the most favourable agricultural areas, with large farms and land parcels, farmers have been likely to allocate most land to grain. The endogenous choice of line of production also has significant statistical implications in relation to profits, output supplies and input demand, known as the self-selection problem.

Within the production line specific profits, supplies and demand, the effect of parcel size dominates over that of distance. Small parcel size was found to hinder farmers from decreasing costs through adopting the most efficient production technologies and production practices. Parcel distance on the other hand did not have any significant effects within the production lines, at least not within the range of variation represented by this sample. Thus the results support the view that small parcel size has significant implications for choice of line of production and, thereafter, also within the chosen line of production. The average distance between the parcels and the farm compound has significant implications only for the choice of line of production. This result suggests that, within the chosen production line, it is easier to adjust farming to long parcel distances than to small parcels.

The ongoing rapid structural development in Finnish agriculture increases the farm size but the parcel size remains practically stagnated. This development implies that the constraints imposed by small parcels of land are becoming more and more costly, since they retard adoption of the most efficient technologies, which are designed for large-scale operations. Traditionally, grassland farming has had comparative advantage in the most fragmented agricultural areas, since the technologies employed in small grass areas have been flexible, and even now the roll-baling technology is flexible enough to be used efficiently on small parcels of land. Nevertheless, the results suggest that grass lands will lose this comparative advantage as farm sizes increase further. The shadow price of parcel size is increasing faster with farm size in grassland farming than in grain cultivation. It is therefore likely that the smallest parcels will gradually be left idle or set aside, even in areas where farms traditionally specialise in cattle rearing and dairying.

The estimates indicate that operations to restructure parcels of land amongst a group of neighbouring farms, although often costly and time consuming, will generate high returns. Since the shadow price for parcel size is increasing with farm size, the current ongoing structural development, which increases the farm size but remains parcel size practically unchanged, is further increasing returns to these operations. It has to be noted that a significant part of the disadvantageous parcel structure is fixed by the natural conditions and, therefore, cannot be improved.

Acknowledgement. Authors thank two anonymous referees for suggestions to improve the manuscript. The financial support received from the Ministry of Agriculture and Forestry is acknowledged. 


\title{
Myyrä, S. \& Pietola, K. Economic importance of parcel structure
}

\section{References}

Akerlof, G.A. 1970. The market for "lemons": Qualitative uncertainty and the market mechanism. The Quarterly Journal of Economics 84, 3: 488-500.

Ala-Mantila, O. \& Riepponen, L. 1998. Maatalouden tuotantokustannukset Suomessa. Abstracts: The production costs of agricultural products according to farm models. Production costs of milk, cereals and pigmeat on bookkeeping farms. Maatalouden taloudellisen tutkimuslaitoksen tutkimuksia nro. 222. 120 p. (in Finnish).

Aaltonen, J., Järvenpää, M., Klemola, E. \& Laurila, I. 1999. Viljan korjuu-, kuivatus- ja logistiikkakustannukset Suomessa. Abstract: Harvesting, drying and logistics costs of cereals in Finland. Maatalouden taloudellisen tutkimuslaitoksen selvityksiä 2/1999. 24 p. (in Finnish).

Chambers, R.G. 1988. Applied production analysis: a dual approach. Cambridge: Cambridge University Press. $331 \mathrm{p}$.

Dougherty, C. 1992. Introduction to Econometrics. Oxford University Press. 399 p.

Heckman, J. 1979. Sample bias as a specification error. Econometrica 47, 1: 153-161.

Keane, M.P. 1993. Simulation estimation of panel data models with limited dependent variables. In: Maddala, G.S. et al. (eds.). Handbook of Statistics. Elsevier, Amsterdam. Vol. 11: 545-571.
Maddala, G.S. 1983. Limited dependent and qualitative variables in econometrics. Econometric society monographs. 401 p. Cambridge.

MMM 1998. Hakuopas 1998. Peltokasvien tuki, ympäristötuen perustuki, luonnonhaittakorvaus ja kansalliset tuet. 114 p. (in Finnish).

Myyrä, S. 2000. Maatilojen tilusrakenne. Abstract: The field structure in the Finnish farms. Maatalouden taloudellisen tutkimuslaitoksen selvityksiä 3/2000. 47 p. (in Finnish).

Sairanen, M. 1998. Lisäpellon etäisyyden vaikutus viljelyn kustannuksiin ja pellon hankintahintaan. Abstract: Effect of the distance to additional arable land on the cultivation costs and acquisition price of arable land. Maatalouden taloudellisen tutkimuslaitoksen selvityksiä 2/1998. 39 p. (in Finnish).

Singh, G. \& Ahn, D.-H. 1995. Relationship between farm land structure and machine efficiency. Journal of Engineering for International Development 2, 1: 2834.

Suomela, S. 1950. Peltojen sijainnin vaikutuksesta maatilan talouteen. Abstract: On the influence of the location of fields on farming. Suomen maataloustieteellisen seuran julkaisu nro. 71.183 p.

\section{SELOSTUS}

\section{Tilusrakenteen taloudelliset vaikutukset}

\author{
Sami Myyrä ja Kyösti Pietola \\ MTT (Maa- ja elintarviketalouden tutkimuskeskus)
}

Suomalaiset tilat kärsivät peltolohkojen pienestä koosta. Kolme neljästä Suomen peltolohkoista on niin pieniä, että niiden koko aiheuttaa viljelyssä merkittävää taloudellista haittaa. Näiden lohkojen osuus Suomen koko viljelypinta-alasta on noin kolmasosa. Nykyiselle maatalouden rakennekehitykselle on tunnusomaista se, että tilakoko kasvaa mutta kasvavien tilojen tilukset säilyvät yhtä pirstaloituneina kuin ennenkin.

Tulokset kertovat maataloudessa ja maatalouden toimintaympäristössä tapahtuneista nopeista muutoksista. Teknologisen kehityksen ansiosta viljelyetäisyyksien aiheuttamat kustannukset ovat laskeneet, mutta lohkokoon merkitys taloudellisena tekijänä on voimakkaasti korostunut. Koneiden ja tilakoon kasvun seurauksena pienistä lohkoista aiheutuvan haitan arvo on noussut merkittävästi.

Perinteisesti tärkeimpänä tilusrakennetta kuvaavana tekijänä on pidetty peltojen etäisyyttä talouskeskuksesta. Tutkimuksessa ei saatu kuitenkaan näyttöä siitä, että tilojen nykyisistä keskimääräisistä viljelyetäisyyksistä olisi merkittävää taloudellista haittaa. Toisaalta tulokset antavat viitteitä siitä, että peltojen pienestä koosta aiheutuvat haitat on aikaisempien tutkimustulosten perusteella aliarvostettu. Nyt saatujen tulosten mukaan tilakoon kasvaessa 10 prosentilla 
Vol. 11 (2002): 163-173.

pienestä lohkokoosta aiheutuva haitta nousee puolitoistakertaiseksi.

Tilakoon kasvu korottaa pienistä lohkoista aiheutuvia lisäkustannuksia nopeammin nurmiviljelyssä kuin viljanviljelyssä. Nurmiviljelyyn perustuva nautakarjatalous on perinteisesti ollut suhteellisesti edullisinta tilusrakenteeltaan epäedullisilla alueilla, minkä vuoksi pientilavaltainen nautakarjatalous on jatkunut epäedullisillakin alueilla. Suomen maatalouden kehityksen kannalta onkin vaarassa, että tilusrakenteel- taan epäedullisille viljelyalueille sijoittunut, nurmiviljelyyn perustuva nautakarjatalous on menettämässä suhteellista etuaan nopean rakennekehityksen mukana.

Lohkokokoa suurentavilla tilusjärjestelyillä saadaan aikaisemmin arvioitua suurempia hyötyjä. Pirstaloituneen tilusrakenteen parantaminen ja lohkojen suurentaminen tilusjärjestelyillä pysyykin ajankohtaisena tavoitteena tilakoon kasvaessa. 
Appendix 1. Parameter estimates and their t-values in the profit, supply and demand equations.

\begin{tabular}{|c|c|c|c|c|}
\hline \multirow{2}{*}{$\begin{array}{l}\text { Profit function } \\
\text { Variable }\end{array}$} & \multicolumn{2}{|c|}{ Grass farms } & \multicolumn{2}{|c|}{ Grain farms } \\
\hline & Parameter & $\mathrm{t}$-value & Parameter & $\mathrm{t}$-value \\
\hline Intercept $\left(\beta_{0}\right)$ & 0.828 & 1.208 & -1.471 & $-2.890 *)$ \\
\hline Crop price a) $\left(\beta_{l}\right)$ & -0.607 & $-2.870 *)$ & -0.630 & $-2.962 *)$ \\
\hline Livestock price $^{\text {a) b) }}\left(\beta_{2}\right)$ & 0.397 & 0.657 & -0.108 & -0.201 \\
\hline Input price a) $\left(\beta_{3}\right)$ & -0.215 & -0.185 & 0.500 & 0.935 \\
\hline Land $\left(\beta_{4}\right)$ & -0.541 & -1.263 & -0.640 & $-2.047 *)$ \\
\hline Capital $\left(\beta_{5}\right)$ & 0.797 & $\left.2.548^{*}\right)$ & 0.604 & $2.057 *)$ \\
\hline Labour $\left(\beta_{6}\right)$ & -0.781 & -0.046 & 0.301 & 1.032 \\
\hline Parcel size $\left(\beta_{7}\right)$ & 0.015 & 0.039 & 0.323 & 0.690 \\
\hline Crop price $•$ land $\left(\beta_{I I}\right)$ & 0.184 & $5.006 *)$ & 1.052 & $\left.8.218^{*}\right)$ \\
\hline Crop price . capital $\left(\beta_{I 2}\right)$ & 0.001 & 0.029 & -0.284 & $-3.055 *)$ \\
\hline Crop price $\cdot$ labour $\left(\beta_{13}\right)$ & 0.013 & 0.271 & 0.174 & 1.794 \\
\hline Crop price $\cdot$ parcel size $\left(\beta_{14}\right)$ & 0.066 & $2.105 *)$ & 0.101 & 0.465 \\
\hline Livestock price $\cdot$ land $\left(\beta_{21}\right)^{\text {b) }}$ & 0.358 & $\left.3.237^{*}\right)$ & -1.126 & $-3.670 *)$ \\
\hline Livestock price. capital $\left(\beta_{22}\right)^{\text {b) }}$ & 1.288 & $14.205 *)$ & 2.182 & $16.394 *)$ \\
\hline Livestock price • labour $\left(\beta_{23}\right)^{\mathrm{b})}$ & 0.992 & $6.954 *)$ & 0.596 & $2.464 *)$ \\
\hline Livestock price - parcel size $\left(\beta_{24}\right)^{b}$ & -0.058 & -0.512 & 0.341 & 0.828 \\
\hline Input price $\bullet$ land $\left(\beta_{31}\right)$ & -0.864 & $-6.784 *)$ & -0.187 & -0.620 \\
\hline Input price - capital $\left(\beta_{32}\right)$ & -1.478 & $15.102 *)$ & -2.112 & $-15.532 *)$ \\
\hline Input price. labour $\left(\beta_{33}\right)$ & -0.463 & $\left.-3.318^{*}\right)$ & -0.619 & $\left.-2.545^{*}\right)$ \\
\hline Input price $\cdot$ parcel size $\left(\beta_{34}\right)$ & 0.250 & 1.804 & -0.342 & -0.897 \\
\hline 0.5 . land squared $\left(\beta_{44}\right)$ & -0.428 & -1.535 & 1.089 & $4.083 *)$ \\
\hline land - capital $\left(\beta_{45}\right)$ & 0.375 & $2.332 *)$ & 0.047 & 0.316 \\
\hline land. labour $\left(\beta_{46}\right)$ & 0.490 & 1.795 & -0.275 & -1.341 \\
\hline land • parcel size $\left(\beta_{47}\right)$ & 0.461 & $2.603 *)$ & 0.195 & 0.797 \\
\hline 0.5 . capital squared $\left(\beta_{55}\right)$ & 0.190 & 1.165 & 0.135 & 0.805 \\
\hline capital • labour $\left(\beta_{56}\right)$ & -0.841 & $\left.-3.983^{*}\right)$ & 0.258 & 1.699 \\
\hline capital • parcel size $\left(\beta_{57}\right)$ & -0.154 & -1.050 & 0.224 & 1.259 \\
\hline 0.5 . labour squared $\left(\beta_{66}\right)$ & 0.876 & $\left.3.146^{*}\right)$ & -0.016 & -0.074 \\
\hline labour • parcel size $\left(\beta_{67}\right)$ & 0.075 & 0.325 & 0.280 & 1.314 \\
\hline $0.5 \cdot$ parcel size squared $\left(\beta_{77}\right)$ & -0.410 & $-2.277 *)$ & -0.993 & $\left.-2.315^{*}\right)$ \\
\hline Inverse Mill's ratio (IMR) & -0.406 & -1.194 & 5.451 & $\left.5.445^{*}\right)$ \\
\hline
\end{tabular}




\section{AGRICULTURAL AND FOOD SCIENCE IN FINLAND}

Appendix 1. Parameter estimates and their t-values in the profit, supply and demand equations.

\begin{tabular}{|c|c|c|c|c|}
\hline \multirow{2}{*}{$\begin{array}{l}\text { Crop supply } \\
\text { Variable }\end{array}$} & \multicolumn{2}{|c|}{ Grass farms } & \multicolumn{2}{|c|}{ Grain farms } \\
\hline & Parameter & t-value & Parameter & t-value \\
\hline Crop price $^{\text {a) }}\left(\beta_{l}\right)$ & -0.607 & $-2.870 *)$ & -0.630 & $-2.962 *)$ \\
\hline Crop price. land $\left(\beta_{I I}\right)$ & 0.184 & $5.006 *)$ & 1.052 & $\left.8.218^{*}\right)$ \\
\hline Crop price $\cdot$ capital $\left(\beta_{12}\right)$ & 0.001 & 0.029 & -0.284 & $\left.-3.055^{*}\right)$ \\
\hline Crop price $\cdot$ labour $\left(\beta_{13}\right)$ & 0.013 & 0.271 & 0.174 & 1.794 \\
\hline Crop price $\cdot$ parcel size $\left(\beta_{14}\right)$ & 0.066 & $\left.2.105^{*}\right)$ & 0.101 & 0.465 \\
\hline Inverse Mill's ratio (IMR) & 0.294 & $\left.2.288^{*}\right)$ & 1.419 & $\left.2.736^{*}\right)$ \\
\hline
\end{tabular}

\begin{tabular}{|c|c|c|c|c|}
\hline \multirow{2}{*}{$\begin{array}{l}\text { Livestock supply } \\
\text { Variable }\end{array}$} & \multicolumn{2}{|c|}{ Grass farms } & \multicolumn{2}{|c|}{ Grain farms } \\
\hline & Parameter & $\mathrm{t}$-value & Parameter & $\mathrm{t}$-value \\
\hline Livestock price $^{\text {a) b) }}\left(\beta_{2}\right)$ & 0.397 & 0.657 & -0.108 & -0.201 \\
\hline Livestock price • land $\left(\beta_{21}\right)^{\mathrm{b})}$ & 0.358 & $3.237 *)$ & -1.126 & $\left.-3.670^{*}\right)$ \\
\hline Livestock price capital $\left(\beta_{22}\right)^{\mathrm{b})}$ & 1.288 & $\left.14.205^{*}\right)$ & 2.182 & $16.394 *)$ \\
\hline Livestock price . labour $\left(\beta_{23}\right)^{\mathrm{b})}$ & 0.992 & $6.954 *)$ & 0.596 & $2.464 *)$ \\
\hline Livestock price - parcel size $\left(\beta_{24}\right)^{\text {b) }}$ & -0.058 & -0.512 & 0.341 & 0.828 \\
\hline Inverse Mill's ratio (IMR) & -0.938 & $-2.562 *)$ & -1.631 & -1.043 \\
\hline
\end{tabular}

\begin{tabular}{lccccc}
\hline Input demand & \multicolumn{2}{c}{ Grass farms } & & \multicolumn{2}{c}{ Grain farms } \\
\cline { 2 - 3 } \cline { 5 - 6 } Variable & Parameter & t-value & & Parameter & t-value \\
\hline Input pricea) $\left(\beta_{3}\right)$ & -0.215 & -0.185 & & 0.500 & 0.935 \\
Input price • land $\left(\beta_{31}\right)$ & -0.864 & $\left.-6.784^{*}\right)$ & & -0.187 & -0.620 \\
Input price • capital $\left(\beta_{32}\right)$ & -1.478 & $\left.15.102^{*}\right)$ & & -2.112 & $\left.-15.532^{*}\right)$ \\
Input price • labour $\left(\beta_{33}\right)$ & -0.463 & $\left.-3.318^{*}\right)$ & & -0.619 & $\left.-2.545^{*}\right)$ \\
Input price • parcel size $\left(\beta_{34}\right)$ & 0.250 & 1.804 & & -0.342 & -0.897 \\
Inverse Mill's ratio (IMR) & -0.802 & $\left.-2.062^{*}\right)$ & & -0.346 & 0.239 \\
\hline
\end{tabular}

The symbols in parentheses are those used in the profit equation (10).

a) since the linear price effects cannot be identified in the profit equation (10), this parameter is in practice a reduced form intercept in the supply or demand equation

b) The term livestock also covers dairy output and prices, depending on the context.

*) Statistically significant at the 5 per cent level. 